\title{
INVESTIGATION OF THE PRETREATMENT EFFECT OF ULTRASOUND ON ANAEROBIC SEQUENCING BATCH REACTOR TREATING LANDFILL LEACHATE
}

\author{
CANAN CAN YARIMTEPE \& NILGÜN AYMAN OZ \\ Canakkale Onsekiz Mart University, Canakkale, Turkey
}

\begin{abstract}
Landfill leachate is one of the most complex wastewaters. Anaerobic treatment has environmental benefits such as low sludge production and biogas production. However, studies have been continuing to achieve better reactor performance. In recent years, ultrasound treatment has been used for different purposes. The aim of this study is to determine the ultrasound effects on anaerobic sequencing batch reactors (ASBR) to increase COD removal efficiency and biogas production for landfill leachate. During operation of ASBRs, in biogas production and methane content, there is an increase of $10 \%$ and $7 \%$ in pretreated leachate, respectively. This increase in reactor performance is directly related to the transition of landfill leachate's organic matter to dissolved phase by ultrasound pretreatment.

Keywords: low frequency ultrasound, anaerobic sequencing batch reactors landfill leachate, biogas production, methane yield.
\end{abstract}

\section{INTRODUCTION}

Solid waste production is rapidly increased worldwide. Although there are alternative methods in solid waste management such as recycling, incineration and composting; landfilling is still the most widely used method of disposal due to practical convenience and economic reasons, especially in developing countries. Leachate is one of the main environmental problems in landfilling. Different treatment methods including, physicochemical (Kang and Hwang [1]; Ramirez and de Velasquez [2]), biological (A $\breve{g} d a g ̆$ and Sponza [3]) and combinations of these methods (Wei et al. [4], Aziz et al. [5]) were tested for leachate, so far. However a complete treatment process for leachate has not been identified due to its complex characterization, so far. Therefore, there is a growing interest in examination of different treatment process for leachate.

Ultrasound process had been used by different purposes for water treatment (Hulsman et al. [6]), industrial wastewater treatment (Matouq and Al-Anber [7]) and sludge treatment (Tiehm et al. [8]). Ultrasound is used as pre or post treatment step to improve the efficiency of biological treatment processes (Lehne et al. [9]). With the application of ultrasound process prior to anaerobic treatment, it is possible to increase organic matter biodegradability and thus more efficient results can be achieved in anaerobic treatment step (Nickel and Neis [10]; Bougrier et al. [11]). It is thought that especially low frequency ultrasound can be used as a treatment method for leachate.

There is limited study about ultrasound treatment for leachate in literature (Wang et al. [12], Neczaj et al. [13]). However, there is only one study about ultrasound pretreatment prior to anaerobic batch reactors for leachate (Öz and Yarimtepe [14]). There is no study about ultrasound pretreatment effect on anaerobic sequencing batch reactors (ASBR), so far.

Therefore in this study, ultrasound pretreatment has been examined for anaerobic sequencing batch reactors. Pretreatment effects have been determined in terms of biogas production and methane yield in ASBR. 


\section{MATERIALS AND METHOD}

The raw leachate samples were taken from Istanbul Environmental Management in Industry and Trade (ISTAC) and their characterization is summarized in Table 1.

Seed sludge samples which were used in ASBR, were taken from a full-scale EGSB reactor feed with brewery factory's wastewater. For seed sludge sample, Total Solids and Total Volatile Solids concentrations were determined as $88,750 \mathrm{mg} / 1$ and $71,450 \mathrm{mg} / \mathrm{l}$, respectively. The methanogenic activity of seed sludge was determined as $456 \mathrm{ml} \mathrm{CH}_{4} / \mathrm{gr}$ TVS day.

A standard generator (Vibra Cell505, $500 \mathrm{~W}$ ) equipped with a metallic probe of $1.9 \mathrm{~cm}$ in diameter, was used in ultrasound experiment. According to recent studies in literature, 250 $\mathrm{ml}$ leachate samples were sonicated with $600 \mathrm{~W} / \mathrm{l}$ at $20 \mathrm{kHz}$ for $45 \mathrm{~min}$. After pretreatment process, tCOD and SCOD were monitored for investigation of ultrasound pretreatment on organic matter biodegradability.

ASBRs were performed in a water bath with temperature $\left(35^{\circ} \mathrm{C}\right)$, and stirring $(90$ $\mathrm{rpm} / \mathrm{min}$ ) control. In the beginning of the study, two parallel ASBRs were fed with raw leachate and $\mathrm{S} / \mathrm{X}$ ratios were gradually increased from 0.1 to 1 substrate/biomass. In reactors were fed daily and each cycle consists of 15 min filling, 23 hours' reaction, 30 min settling and $15 \mathrm{~min}$ discharge duration. The $\mathrm{pH}$ of samples was adjusted to 7 and 1000 to $1500 \mathrm{mg} / \mathrm{L}$ sodium bicarbonate was added in reactors as alkalinity. With the aim of determining the operating efficiency of the reactor, sCOD removal efficiencies, biogas production and methane content were monitored. When the reactors are stable according to sCOD removal efficiencies and biogas production, one reactor was assumed as control reactor and go on fed with raw leachate; the second reactor was fed with ultrasonically pretreated leachate and operation was continued. In this way, it is provided to determine the effect the ultrasonic pretreatment process for ASBRs.

All experimental analyses were carried on according to standard methods (APHA [15]).

Table 1: Leachate characterization.

\begin{tabular}{|l|l|l|}
\hline Parameter & Unit & Value \\
\hline $\mathrm{pH}$ & - & $7.5 \pm 0.15$ \\
\hline Turbidity & $\mathrm{NTU}$ & $1300 \pm 38.25$ \\
\hline Total Suspended Solid & $\mathrm{mg} / 1$ & $2000 \pm 55.72$ \\
\hline Total Chemical Oxygen Demand (tCOD) & $\mathrm{mg} / 1$ & $30500 \pm 413.8$ \\
\hline Soluable Chemical Oxygen Demand (SCOD) & $\mathrm{mg} / 1$ & $14000 \pm 213.54$ \\
\hline Biochemical Oxygen Demand (BOD) & $\mathrm{mg} / 1$ & $11500 \pm 93.08$ \\
\hline Total Organic Carbon (TOC) & $\mathrm{mg} / 1$ & $2100 \pm 88.03$ \\
\hline Total Nitrogen (TN) & $\mathrm{mg} / 1$ & $8050 \pm 21$ \\
\hline Sulphate & $\mathrm{mg} / 1$ & $500 \pm 34.93$ \\
\hline Conductivity & $\mu \mathrm{S} / \mathrm{cm}$ & $41.1 \pm 0.73$ \\
\hline Total Phosphorus (TP) & $\mathrm{mg} / 1$ & $27.5 \pm 1.32$ \\
\hline Nitrate & $\mathrm{mg} / 1$ & $17 \pm 2.3$ \\
\hline
\end{tabular}

$n=10$. 


\section{RESULTS AND DISCUSSION}

With the aim of determining the ultrasonically pretreatment's effect on organic matter degradability; the changes in sCOD/tCOD ratio were investigated in a previous study (Öz and Yarımtepe [14]). In previous study, according to experimental results, 45-min sonication at $600 \mathrm{~W} / 1.20 \mathrm{kHz}$ was selected as optimum condition (Öz and Yarimtepe [14]). Therefore, after 45 min ultrasonically pretreatment, sCOD/tCOD ratio was increased $37 \%$ in optimum condition. Table 2 shows the changes in sCOD/tCOD ratio after pretreatment process.

At the beginning of the ASBR operation, seed sludge in $5000 \mathrm{mg} / \mathrm{l}$ concentration were fed to reactors. For the microorganism activity, seed sludge samples were stored in water bath at $35^{\circ} \mathrm{C}$ without mixing. Both ASBRs were fed with raw leachate and $\mathrm{S} / \mathrm{X}$ ratios were gradually increased from 0.1 to 1 gr COD/ gr VSS in a 24 hours' hydraulic retention time (HRT). During the operation, HRT was adjusted between 1.05 to 1.15 days. In the first 40-day period; both ASBRs were fed with raw leachate and organic loading rate was increased from 0.1 up to $0.9 \mathrm{mg} \mathrm{COD} / \mathrm{mg}$ VSS-day. Table 3 shows the organic loading rate, loading days and COD concentrations which were used during this period.

During the experiments, effluent sCOD concentration and COD removal efficiencies were monitored. In the first 40 operation days, both ASBRs were fed with raw leachate. When organic loading rate was increased to $0.9(4500 \mathrm{mg} \mathrm{COD} / \mathrm{L})$; while one of the ASBR was selected as control reactor and were continuously fed with raw leachate, for the other ASBR, it was started to fed with ultrasonically pretreated leachate for the next one month. sCOD removal efficiencies and biogas production obtained from ASBRs were given comparatively in Figs 1 and 2, respectively.

Table 2: The changes in $\mathrm{sCOD} / \mathrm{tCOD}$ ratio after pretreatment process.

\begin{tabular}{|l|l|l|}
\hline Parameters & Raw leachate & Pretreated leachate \\
\hline tCOD & $30500 \pm 413.8$ & $30540 \pm 217.3$ \\
\hline sCOD & $14000 \pm 213.54$ & $19240 \pm 138.30$ \\
\hline sCOD/tCOD & 0.46 & 0.63 \\
\hline
\end{tabular}

Table 3: Organic loading rate, loading days and COD concentrations.

\begin{tabular}{|l|l|l|l|}
\hline $\begin{array}{l}\text { Organic loading rate, } \\
\text { mg COD/mg VSS-day }\end{array}$ & Loading days & $\begin{array}{l}\text { Microorganism conc. } \\
\text { (mg VSS/L-day) }\end{array}$ & $\begin{array}{l}\text { COD } \\
\text { (mg/L) }\end{array}$ \\
\hline 0.1 & $1-5$ & 5000 & 500 \\
\hline 0.2 & $6-7$ & 5000 & 1000 \\
\hline 0.3 & $8-9$ & 5000 & 1500 \\
\hline 0.4 & $10-11$ & 5000 & 2000 \\
\hline 0.5 & $12-16$ & 5000 & 2500 \\
\hline 0.6 & $17-19$ & 5000 & 3000 \\
\hline 0.7 & $20-22$ & 5000 & 3500 \\
\hline 0.8 & $23-25$ & 5000 & 4000 \\
\hline 0.9 & $26-29$ & 5000 & 4500 \\
\hline
\end{tabular}




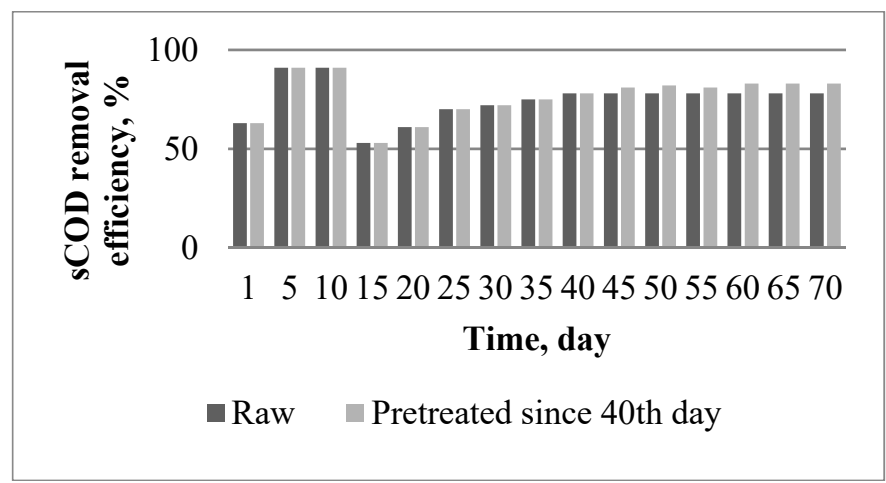

Figure 1: sCOD removal efficiencies for raw and pretreated leachate.

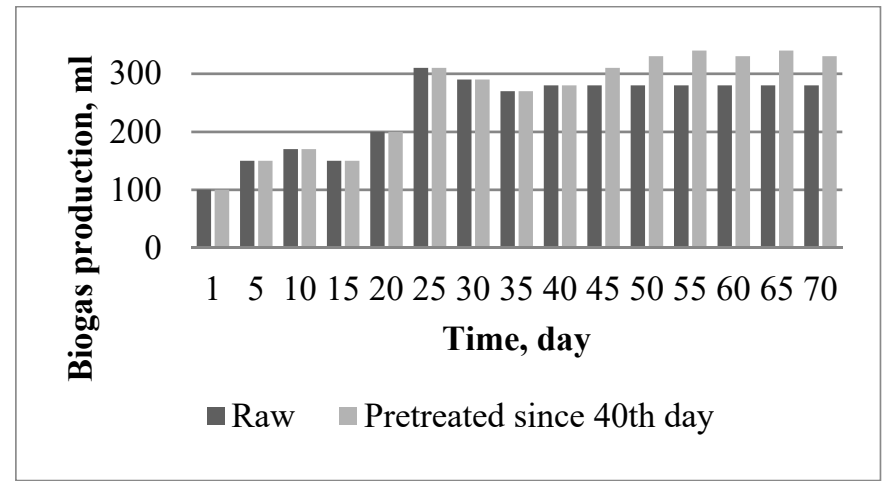

Figure 2: Biogas production for raw and pretreated leachate.

The ASBR were operated with ultrasound pretreated leachate for one month and in this reactor, sCOD removal efficiency was determined as $82 \%$ and there is a $5 \%$ increase in sCOD removal efficiency when compared to raw leachate.

Biogas production in reactor fed with pretreated leachate was increased depending on the increase in SCOD removal efficiency. Average biogas production for raw and pretreated leachate was determined as $300 \mathrm{ml} /$ day and $330 \mathrm{ml} /$ day, respectively. Therefore, there is a $10 \%$ increase in daily average biogas production in pretreated leachate when compared to raw leachate. In addition, methane content of biogas in reactor fed with pretreated leachate, was determined as $70 \%$ with an increase of $7 \%$ when compared to raw leachate.

\section{CONCLUSION}

In this study, the effects of ultrasound pretreatment on anaerobic treatment of landfill leachate are investigated with using ASBRs. In the anaerobic treatment of wastewaters which have high organic matter, it is possible to achieve better reactor performance in terms of COD removal efficiencies and biogas production. According to results, when compared to raw leachate, higher COD removal efficiency and higher biogas production with higher methane content were obtained from The ASBR which fed with pretreated leachate. It is expected to use this combined treatment process for other wastewaters which have high organic content 
and also for other rectors which the hydrolysis step is rate limiting. Also by increase in anaerobic treatment performance with ultrasound pretreatment, smaller reactor volume can be mentioned due to shorter retention time in reactor.

\section{ACKNOWLEDGEMENT}

Financial support by The Scientific and Technological Research Council of Turkey (TUBITAK) was gratefully acknowledged (Project No.: 112Y379).

\section{REFERENCES}

[1] Kang, Y.W. \& Hwang, K., Effects of reaction conditions on the oxidation efficiency in the Fenton process. Water Res, 34, pp. 2786-2790, 2000.

[2] Ramirez, I.M. \& Orta de Velasquez, M.T., Removal and transformation of recalcitrant organic matter from stabilized saline landfill leachates by coagulation-ozonation coupling processes. Water Res, 38, pp. 2359-2367, 2004.

[3] Ağdağ, O.N. \& Sponza, D.T., Anaerobic/aerobic treatment of municipal landfill leachate in sequential two-stage up-flow anaerobic sludge blanket reactor (UASB)/completely stirred tank reactor (CSTR) systems. Process Biochem, 40, pp. 895-902, 2005.

[4] Wei, Y., Ji, M., Li, R. \& Qin, F., Organic and nitrogen removal from landfill leachate in aerobic granular sludge sequencing batch reactors. Waste Manag, 32, pp. 448-455, 2012.

[5] Aziz, S.Q., Aziz, H.A., Yusoff, M.S. \& Bashir, M.J.K., Landfill leachate treatment using powdered activated carbon augmented sequencing batch reactor (SBR) process: Optimization by response surface methodology. J Hazard. Mater, 189, pp. 404-413, 2011.

[6] Hulsman, A. et al., Evaluation of process parameters of ultrasonic treatment of bacterial suspensions in a pilot scale water disinfection system. Ultrason Sonochem, 17, pp. 1004-1009, 2010.

[7] Matouq, M.A. \& Al-Anber, Z.A., The application of high frequency ultrasound waves to remove ammonia from simulated industrial wastewater. Ultrason Sonochem, 14, pp. 393-397, 2007.

[8] Tiehm, A., Nickel, K. \& Neis, U., The use of ultrasound to accelerate the anaerobic digestion of sewage sludge. Water Sci and Technol, 36, pp. 121-128, 1997.

[9] Lehne, G., Müller, A. \& Schwedes, J., Mechanical disintegration of sewage sludge. Water Science \& Technology, 43, pp. 19-26, 2000.

[10] Nickel, K. \& Neis, U., Ultrasonic disintegration of biosolids for improved biodegradation. Ultrason Sonochem, 14, pp. 450-455, 2007.

[11] Bougrier, C., Albasi, C., Delgenès, J.P. \& Carrère, H., Effect of ultrasonic, thermal and ozone pre-treatments on waste activated sludge solubilisation and anaerobic biodegradability. Chem Eng and Process: Process Intensif, 45, pp. 711-718, 2006.

[12] Wang, S., Wu, X., Wang, Y., Li, Q. \& Tao, M., Removal of organic matter and ammonia nitrogen from landfill leachate by ultrasound. Ultrason Sonochem, 15, pp. 933-937, 2008.

[13] Neczaj, E. et al., Effect of sonication on combined treatment of landfill leachate and domestic sewage in SBR reactor. Desalination, 204, pp. 227-233, 2007.

[14] Öz, N.A. \& Yarimtepe, C.C., Ultrasound assisted biogas production from landfill leachate. Waste Manag 34, pp. 1165-1170, 2014.

[15] Standard Methods for the Examination of Water and Wastewater, 19th ed., APHA, AWWA, WPCF: Washington, DC, 1995. 